\title{
Factors and Issues on Treatment Adherence among Filipino Patients with Epilepsy and their Caregivers
}

\author{
Ranhel C. De Roxas, ${ }^{1}$ Joshua Emmanuel E. Abejero ${ }^{1}$ and Leonor I. Cabral-Lim ${ }^{2}$ \\ ${ }^{1}$ Department of Neurosciences, Philippine General Hospital, University of the Philippines Manila \\ ${ }^{2}$ Department of Neurosciences, College of Medicine and Philippine General Hospital, University of the Philippines Manila
}

\begin{abstract}
Background. Non-adherence to treatment in epilepsy is considered as a worldwide problem ranging from $30-50 \%$ of patients. Despite its striking magnitude, only a few studies tried to explain the factors affecting it. Moreover, a standard method to measure adherence to treatment among patients is still lacking. An in-depth analysis on adherence to treatment of patients with epilepsy, taking into factor their values, beliefs, and culture, is deemed necessary.
\end{abstract}

Objectives. The purpose of this qualitative study is to investigate the contributory factors and issues on treatment adherence faced by Filipino patients with epilepsy and their caregivers. This study also aimed to serve as a catalyst to further stimulate local researches on treatment adherence in epilepsy.

Methods. Four focus group discussions were conducted with patients and caregivers who voluntarily agreed to participate and share their experiences on dealing with epilepsy. A total of 39 participants were included. The focus group discussions, facilitated by skilled moderators, were composed of an ice breaker and a discussion on the experiences and issues faced by the participants. The discussions were transcribed and analyzed using thematic coding.

Results. Three main content categories were identified from the focus group discussions, namely, 1) accepting a life with epilepsy, 2) dealing with the disease, and 3) ensuring freedom from seizure attacks, which were further sub-categorized. From these, a number of factors affecting treatment adherence were identified and a conceptual framework was developed by the investigators.

Conclusion. This study was able to demonstrate that conducting a focus group discussion was an effective means of eliciting the experiences and issues in patients and their caregivers. Several factors affecting treatment adherence such as patient-doctor relationship, financial resources, government support, adverse medication effects, religious belief, trigger avoidance, frequent reminders, and safety precautions were elucidated in this study.

Key Words: epilepsy, treatment adherence, focus group discussion

Corresponding author: Ranhel C. De Roxas, MD

Department of Neurosciences

Philippine General Hospital

University of the Philippines Manila

Taft Ave. Ermita, Manila, 1000 Philippines

Telephone: +632 5548462

Email: rhainderoxas@yahoo.com

\section{Introduction}

Epilepsy is a condition which affects people regardless of age, race, sex, and socioeconomic status. This can lead to decline in the quality of life, loss of productivity, and even death if left untreated. In diagnosed patients who have started on anti-epileptic drugs, 70\% can become seizure-free. Adherence to treatment is an integral part of its management, however, non-adherence is still frequently seen. The World Health Organization considers nonadherence to treatment as a worldwide problem of striking magnitude. ${ }^{1}$ Several studies had been done to measure nonadherence in people with epilepsy (PWE); and this ranges from $30-50 \%$ throughout the years. ${ }^{2,3}$ In developed countries, contributory factors to non-adherence were due to educational, cultural, socioeconomic, lifestyle and health care access, and delivery barriers. ${ }^{4}$

Adherence to treatment in epilepsy is yet to be defined. ${ }^{3}$ It can refer to taking of medication at a given time as prescribed by the physician. Others define adherence as being able to take the required number of medication at a given time interval. Others may pertain to adherence as the absence of seizures despite missed doses. For some, it actually pertains to the extent of the behavior of the patient towards taking the medication after an agreement with their physician. However, there is yet no gold standard method to measure treatment adherence. In the United States, the Morisky Medication Adherence Scale is used to estimate a patient's adherence to treatment in chronic diseases such as epilepsy using a scaled questionnaire. ${ }^{5}$ Initially, it was composed of only four questions with a sensitivity and specificity of $81 \%$ and $44 \%$, respectively. It was later improved to include eight questions to account for better psychometric properties with a sensitivity of $93 \%$ and specificity of 53\%. Despite its popularity, the Morisky Medication Adherence Scale was found to have inconsistencies with translational and content validity in different diseases. ${ }^{6}$ In the United Kingdom, the Belief about Medicines Questionnaire is used to determine the beliefs of the patient on treatment adherence, however, it was found to have weak validity when translated to other languages. ${ }^{2,6}$ Moreover, these measures may not be applicable in the local setting especially that most medications are obtained as an out-of-pocket expense, as opposed to that in developed countries. In the Philippines, a validated tool to measure treatment adherence among PWE is still lacking. This will 
require an in-depth analysis on the adherence to treatment of PWE, and it is important to take into factor the values, beliefs, and culture of the patient and caregiver.

\section{Conceptual framework}

Based on the literature, the people involved to ensure treatment adherence include the PWE and their caregivers (Figure 1). In this study, we took into consideration their beliefs, values, and cultural background.

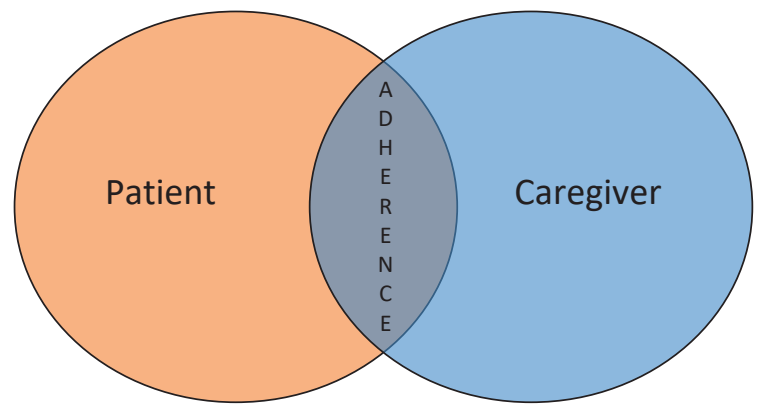

Figure 1. Conceptual framework of treatment adherence in epilepsy.

\section{Objectives}

The purpose of this qualitative study was to investigate the contributory factors and issues on treatment adherence faced by Filipino patients with epilepsy and their caregivers through a focus group discussion. To this end, the following questions were explored: 1) What are the patterns of treatment adherence from the patient's perspective? 2) What are the perceived factors contributing to the adherence to medical treatment among people with epilepsy and their caregivers? and 3) What patient measures are done to ensure treatment adherence? This study will serve as a catalyst to further stimulate local researches on treatment adherence in epilepsy.

\section{Methods}

\section{Study design and study population}

Focus group discussion was used to gather the needed data in this study. This is an ideal method to elicit subjective insights and concerns of the patients, as well as of the caregivers. The study was designed to meet the quality criteria for qualitative research as defined by Critical Appraisal Skills Programme guidelines. ${ }^{7}$

\section{Sampling and randomization}

Convenient sampling was used in this study. During the annual celebration of the Epilepsy Week last September 2016 in the Department of Neurosciences of the Philippine General Hospital, a committee composed of Neurology residents invited PWE listed in the Epilepsy patient database to participate in the lay forum which was conducted during the said week. The committee also invited the eligible epilepsy patients and their caregivers to participate in a focus group discussion. Only those who voluntarily agreed to participate were included; nobody was coerced in any way to join the discussion. The investigators explained the process of the discussion, its benefits and consequences and asked the participants to sign a consent form. A total of 39 participants were included in this study. One of the registered participants did not arrive during the focus group discussion. The participants were divided into four focus groups composed of nine or ten participants in each group. The first two groups were composed of patients with epilepsy while the other two groups were composed of the caregivers of the patients with epilepsy. The focus group discussions were facilitated by trained and experienced psychologist moderators. The participants who were included in the discussion were those 1) aged between 18 years 0 months and 60 years 0 months, 2) with a diagnosis of epilepsy for at least six months duration or a caregiver of a person with epilepsy for at least six months, 3) who were patients of the Neurology Outpatient Clinic or their caregivers, and 4) who were able to participate verbally in a group discussion. The investigators did not participate in any of the focus groups.

\section{Data collection}

Four focus group discussions consisting of patients and caregivers were conducted in four separate rooms to ensure privacy. The group discussions were audio-taped to enable verbatim transcription. Each participant was assigned a code upon producing the verbatim transcription. The first element of the code was their group number (1-4), the second was whether they are a patient $(P)$ or a caregiver $(C)$, and the last was their age. During the focus group discussion, the moderator also observed the behavior and non-verbal cues of the participants.

Each focus group discussion was comprised of three main sections. The first section served as an icebreaker in which everybody introduced and described herself/himself. The second section was a discussion on the experiences of the patients on dealing with epilepsy and of the caregivers on taking care of the patients with epilepsy. This led naturally into further discussion about the issues on epilepsy which comprised the third section. A list of questions was given to the moderators, however, these questions only served as a guide for the flow of the discussion and did not serve as script during the discussion (Table 1).

\section{Study analysis}

The data were encoded and analyzed using thematic coding. Discussion notes were transcribed electronically by a skilled transcriber and sent to the investigators for review. The investigators conducted analysis of the transcription by 1) reading through it without taking down notes, 2) going through the transcription again and 
Table 1. Guide questions for the focus group discussion

\begin{tabular}{ll}
\hline I. Patients & II. Caregivers \\
\hline $\begin{array}{l}\text { 1) When did you begin treatment } \\
\text { for epilepsy? Describe your }\end{array}$ & $\begin{array}{l}\text { 1) What are the challenges you faced } \\
\text { in caring for a person with epilepsy? }\end{array}$ \\
$\begin{array}{l}\text { 2) Do you take your medication } \\
\text { regularly? If so, how often is }\end{array}$ & $\begin{array}{l}\text { 2) Did you have any difficulty in } \\
\text { providing the prescribed treatment } \\
\text { regular? If not, why not? What } \\
\text { can be done to improve this? }\end{array}$ \\
$\begin{array}{ll}\text { 3) What is the single most } \\
\text { important issue in getting the } \\
\text { medical treatment you want? }\end{array}$ & $\begin{array}{l}\text { 3) If you have the opportunity to say } \\
\text { anything you want to a physician } \\
\text { about improving care for epilepsy, }\end{array}$ \\
$\begin{array}{ll}\text { 4) How supportive has your } \\
\text { family been since you've had } \\
\text { epilepsy? }\end{array}$ & \\
$\begin{array}{l}\text { 5) What do you do to ensure } \\
\text { treatment adherence? }\end{array}$ & \\
\hline
\end{tabular}

creating a list of the major points from the discussion, and 3) defining the content categories from the initial list obtained. This process was repeated for the other three transcriptions. Using the content categories and the experiences expressed by the participants during the discussion, the investigators pulled together the data in an attempt to achieve a level of depth in understanding the factors and issues affecting the treatment adherence among the patients and their caregivers.

\section{Ethical considerations}

The research protocol was submitted to a Research Ethics Board panel for ethics review and approval. The study was conducted only upon approval from the panel. Participants were not coerced in any way to join the discussion and were only included upon signing the consent form. Participants of the focus group discussion were given certificate of participation after the session. To further increase the atmosphere of collegiality, food and refreshments were served throughout the duration of the discussion. No monetary reward was given. The anonymity of subjects, as well as the confidentiality of the data obtained, were assured by the investigators. All data were recorded only in writing. The audio-taped recordings of the discussion were erased after the written transcription was obtained. The results and patient information were kept strictly confidential by the primary investigator. The benefit and harm were explained to the participants. Their benefit included knowing the issues that affect treatment adherence and addressing the issues eventually upon consolidating the results. No direct harm was intended in this study except for their identity that was addressed by ensuring anonymity through the use of coding.

\section{Results}

Even though the recommended number of focus group discussion questions was followed in this study, ${ }^{8}$ two focus group discussions exceeded 90 minutes in duration. This was probably a result of the openness and willingness of the participants to share their experiences, concerns, and issues on how they live with epilepsy and how they deal with it. One of the moderators commented that the discussion eventually became free-flowing toward the middle part because the participants already took the initiative to share their experiences.

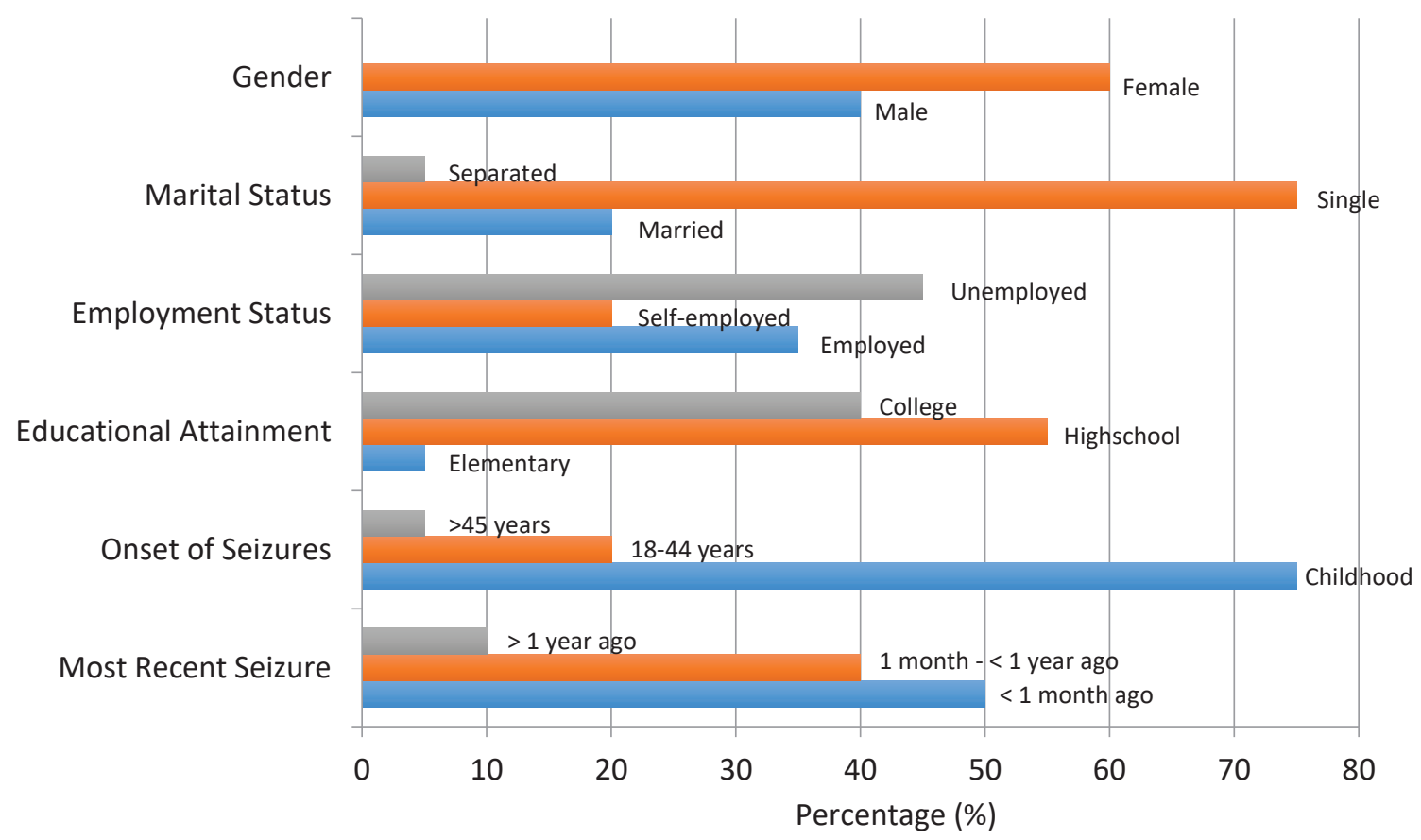

Figure 2. Characteristics of the people with epilepsy who joined the focus group discussion. 
The PWE included in the discussion had a mean age of 34.9 years (range: 20-54 years) with the duration of epilepsy ranging from one year to thirty seven years. Figure 2 shows the characteristics of the PWE in the focus group discussion. On the other hand, the caregivers had a mean age of 48.2 years (range: 21-69 years). Majority of the caregivers were parents of the PWE (73.7\%) who relied on their salary to augment the needs of their patient. (Supplemental Table 1).

The theme categories and sub-categories identified by the investigators are summarized in Table 2. A collaborative effort to include quotations from each of the focus groups was made to ensure that the findings were consistently noted. After each quotation, the group number and the page number in the transcription were cited (FG\#, p. \#). The three main categories identified from the focus group discussion transcripts were 1) accepting a life with epilepsy, 2) dealing with the disease, and 3) ensuring freedom from seizure attacks.

Table 2. Content categories and sub-categories identified during the focus group discussion

\begin{tabular}{lc}
\hline \multicolumn{1}{c}{ Category } & Sub-category \\
\hline Accepting a life with & Denial with the diagnosis \\
epilepsy & Stigma of epilepsy \\
& Restrictions with activities \\
Pursuit to live a normal life & Patient-doctor relationship \\
Dealing with the disease & Treatment cost \\
Government support \\
Medication side effects \\
Self limitations \\
Dedication of the caregivers \\
Community awareness \\
Safety precautions \\
Fnsuring freedom from \\
seizure attacks \\
Making up for missed doses \\
Significant people in life \\
Religious belief \\
Trigger avoidance \\
\hline
\end{tabular}

Accepting a life with epilepsy

The stories of the participants during the ice breaker of the focus group discussion were noted to start during the time they learned that they have epilepsy. For the investigators, this is an important finding since we will be able to understand where the participants are coming from and to somehow assess the quality of their lives. For the patients, epilepsy is a challenging condition requiring enough courage to live every single day with it. For the caregivers, it really entails significant amount of time and effort to look after their patients with epilepsy.

\section{Denying the diagnosis}

Majority of the participants did not know of epilepsy until they themselves or their loved ones already experienced the seizure attacks and consulted their doctors. At first, some of them thought that it was just an ordinary condition just like other illnesses but when they experienced recurrent seizure attacks, they realized that it is not something to be taken for granted. One of the participants even commented that in order to live a life with epilepsy, it should be accepted as part of one self.

'Yung self-denial na "Ay wala akong ganito!" kailangan maging honest tayo sa sarili natin, maging honest din tayo sa kapwa natin. (In self-denial, we tell ourselves "I don't have this" but we should be honest to ourselves and to other people) (FG 1, p.13)

Stigma of epilepsy

During the focus group discussion, most of the participants were noted to suffer from the social label of the disease. Some of the PWE present during the focus group discussion suffered from the unending teasing of other people who said that they were not normal. Others experienced discrimination from school and work. Two of the participants reported that they were being treated like a child or someone who needs special attention by other people, and sometimes even by their own family, which actually did not help them cope up with their condition.

Kapag nakikita ako ng mga tao, hindi naman ako humihingi, binibigyan nila ako ng pera. (When people see me, even if I don't ask them, they give me money) (FG 1, p.3)

Sa akin naman po kasi, honestly speaking po, sa pamilya ko, ang tingin nila sa akin parang iba po eh. Nasabi na po mismo sa akin na nakakahiya ako kapag nagsusumpong. (For me, honestly speaking, my family sees me differently. They even told me before that it is shameful to have seizure attacks) (FG 1, p.14)

Nag-aral siya, nakagraduate, nag-aral pa siya noon ng accountancy pero dahil sa discrimination, hindi siya natanggap sa trabaho (He studied and graduated in accountancy but he was not accepted for a job because of discrimination) (FG 4, p.5)

\section{Restrictions with activities}

The participants felt that epilepsy set numerous limitations in their life. Some of the PWE were deprived of doing even simple things in the fear that it can trigger a seizure attack. On the other hand, some of the caregivers cannot work productively anymore because they have to watch over their patient.

Gusto ng magulang ko, huwag daw akong palaging palakadlakad. Eh ayoko po naman na palagi akong nakahiga sa loob ng bahay namin. Ang iniisip ng nanay ko, baka sumpungin daw ako. (My parents won't allow me to wander around because I might get seizure attacks, but I don't want to lie down all day at home.) (FG $1, p .3)$

\section{Pursuit to live a normal life}

All of the participants desired living a normal life despite all the difficulties they faced because of the disease, either as a patient or as a caregiver. Rather than worrying about the complexities of epilepsy, they tried to divert their attention to something else, which can usually make them productive members of the society. 
Sa ngayon kasi nilalaro ko na lang ang buhay ko eh, kung saan ako masaya, na mamuhay nang normal. Hindi ko na rin iniisip yun eh ang sakit natin kasi minsan hindi siya dumarating kasi hindi natin siya iniisip kaya nabubuhay rin tayo nang normal gaya ng ibang tao. Kaya gusto natin na malaya tayo na walang sagabal sa ginagawa natin. (For now, I just live with my life happily. I don't want to think about my illness because I can live normally like other people. We want to do things our own way without any hindrances.) (FG 1, p.16)

\section{Dealing with the disease}

Accepting a life with epilepsy and trying to achieve seizure freedom were the main goals of the participants as elicited during the focus group discussion. In order to attain this, the patients and their caregivers should learn how to deal with epilepsy and a number of factors affecting this were identified during the focus group discussion.

\section{Patient-doctor relationship}

All of the participants believed that a good patientdoctor relationship is the most important key to the success in the treatment process of epilepsy. For some, effectively communicating with their doctors helped them overcome their hardships in living with epilepsy. However, others were hesitant to talk about their relationship with their doctors because they felt that they were not given enough attention and information that they needed.

Ang pinakamaganda talaga yung komunikasyon sa doktor. You know how to communicate to your doctor. Sasabihin mo kung ano ang nararamdaman mo. Kaya kung sunod-sunod ang schedule ko sa doktor, hindi ako nanghihinayang sa pera. Pramis. Pumupunta talaga ako no matter what happens. Bumaha, bumagyo, talagang pupunta ako. Nagbabaon ako ng damit para pagdating ko dito makapagbihis ako. Kasi ang number one rule ng doktor, maayos tayo makipagcommunicate. (It is best to communicate with the doctor. Tell him what you feel. Even if I have several schedules with my doctors, I never hesitated with the finances. I always go to them no matter what happens.) (FG 1, p.12)

Eh si Doc kasi napakabait talaga. Talagang "Nanay, kamusta ka na?" Nakakaano sa pasyente 'yun kahit na ganyan lang, parang mahal na mahal ka niya. Sa akin lang healing process din 'yun eh. Yung tina-tap mo siya, kinakamusta mo siya. Di ba kapag may alaga kang pasyente, stressed ka rin. Di mo alam ang gagawin. Nakatulong talaga 'yun. (My doctor is very nice. It feels good for a patient that your doctor cares about you. It becomes part of the healing process. Even a simple tap or a "how are you" remark is something for us.) (FG 3, p.10)

\section{Treatment cost}

Since most of the participants got their medications from out of the pocket, the cost of the consultation, medication, and even transportation to the hospital was a big hindrance for them to adhere to the prescribed treatment regimen. Some patients resorted to missing their medications while some of the caregivers tried to get donation from other people.

Hindi ko po masyado nasusunod eh kasi minsan kinakapos ako sa budget dahil may anak pa po ako at ako lang rin po naghahanapbuhay. Budget po talaga. Kasi nag-aaral pa ang anak ko, gastos pa sa pagkain tapos bibili ng gamot. Kasi nadadagdagan po eh. Una phenobarbital lang eh. Ngayon dinagdagan ni Doktora ng carbamazepine. Kumbaga mahirap sa budget eh. Yung kita ko, halos ang puhunan ko nababawasan na rin sa pagbili ng gamot. Kaya ang nangyayari, hindi ako nakakainom nang regular. (I sometimes miss my medications because of budget constraints especially that my child and I are the breadwinners in the family. Before I was on Phenobarbital but my doctor has to add Carbamazepine now to control my attacks. Sometimes, my earnings only go to my medications) (FG 1, p.7)

Minsan po kapag walang pambili ng gamot kasi nagtaning siya noon, ginagawan ko ng paraan. Nanghihingi ako sa mga kakilala ko ng donation. (Sometimes, when I don't have money to buy my medications, I ask help for donations.) (FG 4, p.2)

\section{Government support}

According to the participants, several government programs provide some help in order for them to buy the medications they need. The disability card, which is used by almost all the participants, offers a big discount on purchasing the antiepileptic drugs. Different government agencies such as the Philippine Charity Sweepstakes Office, Philhealth, and the Department of Social Welfare and Development were also mentioned to provide medications although the details were not discussed anymore. One of the participants was even pushing for tax exemption for PWE.

Ginagamit ko ang ID ko na may $20 \%$ discount sa PWD. (I use my PWD ID to avail $20 \%$ discount) (FG 1, p.7)

\section{Medication side effects}

Majority of the participants reported that some drugs are better for them compared to others because of the difference in side effects. Some of the patients reported missing their medications in order to avoid the unwanted side effects after. Majority of the patients were on phenobarbital, probably because of the cheap cost, and many reported that they sometimes fail to take this drug because of the sleepiness and memory lapses.

Ang side effect kasi sa akin dati ng phenobarbital is almost 16 hours akong tulog. Tapos hindi ako nakakakain kasi tulog ako nang tulog. Pagkagising ko, kakain na naman ako tapos matutulog. So windang ako lagi. After a month, pinalitan ni Doc ng carbamazepine. Nagslow-speech naman ako noon.Tsaka para akong robot. So ano, binigyan ako ng levetiracetam. Doon naman, nagwild ako doon. Pero tumagal ako doon kasi nakakatulog ako. 'Yun nga lang, ang epekto sa akin noon, masyado akong hyper. Masyado akong - konting kaluskos lang o anong marinig ko na salita, nang-aaway ako. Nagkaroon ako ng kaso kasi nakabugbog 
ko. Kaya pinalitan na lang ng lamotrigine. (I go into 16 hours of sleep as a side effect of Phenobarbital. It resulted to less food intake because of its drowsy effect. After a month, my doctor changed it to Carbamazepine then my speech became slow and robotic. Then they shifted it to Levetiracetam. But I had behavioral changes with it but I endured that for a time. It came to a point where I easily get irritated. Then they changed my medication to Lamotrigine) (FG 1, p.8)

\section{Self limitations}

Some of the participants reported some factors inherent to oneself as reasons why there are times that the medications will be missed. In one of the groups, the participants were asked to rate their treatment adherence and it was noted to range from $10-100 \%$ because of simple reasons such as forgetfulness, sleeping during the time for medication intake, and laziness to take their medications.

Pero minsan po hindi ako nakakainom kasi gusto ko matagal ang tulog ko kapag tanghali. (Sometimes, I fail to take my medication because of too much sleep at noon.) (FG 1, p.8)

\section{Dedication of the caregivers}

The show of caregivers' dedication to take care of the patients with epilepsy was very striking during the focus group discussion. Most of them allotted most of their time looking after their patient, sometimes to a point of losing their jobs. However, many of the caregivers also claimed that their patients were very stubborn and they attributed this to their condition, and sometimes to the medications.

Naku pinapagalitan namin 'yan dahil kainitan ng araw nagbabasketball. Ayaw namin na baka bumagsak siya. Yung mga kapatid naman niya, kasi siya ang panganay, pinapabantay ko doon baka mamaya biglang atakihin. Mamaya shoot nang shoot ng bola yan tapos manigas na. Noong isang araw lang sinumpong sa labas ng bahay. Itong bunso ko na 10 years old napansin niya. Inalayan niya, niyakap niya. Sabi niya tawagin niyo si mama kasi sinusumpong. (We would discourage him to play basketball because we don't want him to get an injury because of a seizure attack. His siblings look after him. Just the other day, he had an attack outside our house. It was a good thing that his younger brother saw and attended him when he fell on the ground) (FG 4, p.7)

Kapag hindi pa nakauwi 'yan, hinahanap ko talaga 'yan. Talagang mahirap. Wala ka nang maisip kung kailan siya susumpungin o kung saan na wala siyang kakilala. (When he's not yet at home, we really look for him. It was hard because we don't know when he would have his attacks.) (FG 4, p.11)

\section{Community awareness}

For the participants, being surrounded by people who understand epilepsy is a big help for them in dealing with the disease. Community awareness should be advocated and was identified to be a significant factor affecting the PWE and their families.
Una pag-unawa na tanggapin ang pasyente, lalo na kapag mainit ang ulo. Kasi kailangan unawain talaga. (It is very important to understand these patients) (FG 3, p.14)

Marami ho sa bansa natin na hindi nakakaunawa sa mga Person with Disability na hindi naman nila kasalanan. Siguro kasi hindi po nila naiintindihan. (Many people in our country do not understand a person with disability.) (FG 4, p.5)

Ang dami pong tumutulong sa amin, sa church namin, mga pamilya namin, sa neighborhood, sa barangay namin tsaka sa city hall rin po. (Many people are helping us; in our church, in our family, in our neighbourhood, even our city government.) (FG 4, p.11)

\section{Safety precautions}

It is very important for the participants to ensure the safety of the patient at all times because the consequences of seizure attacks cannot be predicted. Most of the caregivers do not want their patients to go out alone or to do something alone because of the fear that something might happen and nobody will care for their patient.

'Yung kwarto niya may rubber mat kasi hindi maiiwasan na bumagsak siya. Minsan nung nakatulog ang asawa ko, hindi na nabantayan na nabagsak siya doon sa bandang unahan. Tsaka pati yung sahig namin sa taas. (His room has a rubber mat because we cannot avoid him falling during attacks.) (FG 4, p.4)

\section{Ensuring freedom from seizure attacks}

Despite the many factors and issues faced by the PWE and their caregivers, being able to achieve seizure freedom is still considered to be an attainable and realistic goal in the life of the participants.

\section{Frequent reminders}

For most of the participants, it was really helpful when there are reminders that they see everywhere telling them that they need to take the medication. Some of them would put their medications in a place that will make them not forget such as the table top or their pockets or even underneath their pillows. Most of the patients forget to take their medications but the caregivers really find ways to remind them at all times.

'Yung ginagawa ng anak ko sa bahay, "Mama take your medicine 8 o'clock in the morning." Meron sa kubeta, sa kusina. Meron din sa sala. Kaya nahihiya na ako sa bandang huli. Tinatanggal ko. Sinisigawan ako ng asawa ko na "Hoy uminom ka ng gamot! Para hindi ka maging imaw!" Kaya ngayon nakaugalian ko na. Dati talagang noong medyo imaw pa ako, lahat ng dingding may mga nakadikit. Sa sala, sa kusina, sa kubeta, sa laundry area kasi nakakalimutan ko. (What my daughter does is she put reminders everywhere - in the toilet, kitchen or even in the living room. My husband would shout at me to remind me to take my medication. That is why now, I am already used to taking my medication.) (FG 1, p.11) 
'Yun lang kailangan isusulat ko kasi para bang nagiging makakalimutin ako. (I have to write it down because I think I'm becoming forgetful) (FG 2, p.13)

\section{Making up for missed medication doses}

Some of the participants make up for their missed doses of medication. For instance, after missing the evening dose of their medication, they will take double of the dose in the morning so that they feel that they are still compliant to their medications.

'Yung ginagawa ko po kapag nakakalimutan ko, dalawang tabletas po ang iniinom ko. (What $I$ do is I take two tablets whenever I forget to take my medication.) (FG 1, p.10)

\section{Significant people in life}

All the participants find it important that PWE be accepted and supported strongly by their family as well as other significant people around them to help them deal and succeed in dealing with epilepsy.

Pagdating sa family, sa emotional support, masasabi ko na $100 \%$ sila. Iba-iba kasi ang case ng patient, may mga financial support na hindi kayang punan. Kaya hindi rin natin masabi na hindi sila supportive kasi kung sa financial minsan walang magagawa pero sa emotional, 100\% talaga. (My family has 100\% emotional support. But for financial problems, they cannot do anything about it. Again emotionally, they are really $100 \%$ supportive) ( $F G$ 1, p.14)

Gaya ng asawa ko, hindi n'ya ako pinapabayaan na magisa lang ako. Laging kasama ko siya kung saan ako pupunta. (My husband never leaves me alone. He is always with me wherever I go.)

\section{Religious belief}

Majority of the participants also turn to their religious belief as a means of ensuring that their seizures are controlled. For them, the power of prayers is indeed an effective tool in achieving freedom from seizure attacks.

Sa simula po, nagpray ho ako sa simbahan, nagrosary ako mula pintuan hanggang altar. Sabi ko sana mahinto na 'tong panginginig ko dahil nakakahiya na sa mga tao. Yung makikipagkwentuhan lang ako - konting kwentuhan lang, bumabagsak. Hanggang sa 'yun nagkaroon ng means. Walang katapusang pasasalamat kasa nahinto na ako. (I always pray in the church, I would pray the rosary from the church door up to the altar. I always pray that my seizure attacks will stop because I feel ashamed. Now, I am very much thankful that my attacks stopped.) (FG 1, p.1)

\section{Trigger avoidance}

Even if the patients were taking their medications, they were noted to have seizure attacks whenever they fail to avoid the triggers. Hunger, excessive thinking, lack of sleep, and stress were the triggers usually reported during the focus group discussion.
'Yun na ng napansin namin. Kapag gutom ako, inaatake ako. (We noticed that I will get seizure attacks whenever I am hungry.) (FG 1, p.8)

Sa akin kasi ang technique ko naman diyan, kung walang gamot, control sa sarili. Halimbawa hindi ka nakainom ngayon ng gamot, dapat huwag kang masyadong magpagod. Kasi kapag nagpagod ka talaga, aatakihin ka. Minsan kung wala kang iniinom na gamot, kapag masaya ka kasama ang barkada mo, pamilya mo, hindi naman siya umaatake eh. Ang sakit nga natin nasa isip eh. Kung hindi natin siya iniisip, hindi naman siya dumarating. Kaya nililibang ko nalang ang sarili ko. Kung saan ako masaya, doon ako. (For me, my technique is to control myself even if I don't have any medication. For example, I fail to take my medication now, I will make sure that I will not get tired because it will really trigger my attack. Sometimes, when I fail to take my medication, as long as I am happy with my family and friends, I will never get an attack. Sometimes, the illness is just in our mind so whenever we don't think about it, it will never manifest.) (FG 1, p.16)

\section{Discussion}

The use of focus group discussion, which was employed in this study, is a very effective approach to uncover the experiences of the people with epilepsy and their caregivers. ${ }^{8}$ In the four focus group discussions conducted, it was noted that the experiences and issues shared by the participants were similar as reflected by the three major categories identified by the investigators. These similarities strengthen the findings of this study.

The participants shared their experiences from the time of epilepsy diagnosis. Epilepsy, which is actually a benign condition effectively controlled with antiepileptic drugs, is shown to cause a multitude of physical, psychological, social and religious repercussions not just to the patients but also to the caregivers. In a review by Jacoby et al, the stigmatising stereotype of epilepsy can be explained by the threat and fear experienced by the terrified watchers during a seizure attack where a patient lose control of himself. ${ }^{9}$ Achieving good quality of life and seizure freedom through adherence to treatment was identified as one of the most important concerns in the management of epilepsy. ${ }^{10}$

In this study, a number of factors affecting treatment adherence were identified. First, a good patient-doctor relationship is very important. In a study by Ridd et al, a good patient-doctor relationship is built in four elements: knowledge, trust, loyalty, and regard, which should be reciprocal. ${ }^{11}$ This is probably the reason why it was repeatedly stated during the focus group discussion that the participants expect the doctors to provide them the required knowledge, to listen to what they have to say about their experiences and to show concern to them. The unwanted side effects of the medications were also shown to be a big concern not just for the patients but also to the caregivers. Dizziness, nausea, memory lapses, and irritability were the common adverse effects of antiepileptic drugs reported 
during the discussions, and these were also frequently seen in other studies. Minimizing and addressing these adverse effects may positively affect the adherence to treatment of PWE. ${ }^{12,13}$ It was also noted that recognizing the inherent self limitations of the PWE, providing frequent medication reminders and ensuring trigger avoidance are keys to better treatment adherence. In a study by Balamurugan et al, PWE should avoid emotional stress, sleep deprivation, fatigue, missing meals, and smoking. ${ }^{14}$ The availability of financial resources and government support were also clearly shown to affect treatment adherence. Lastly, the religious belief of the participants was also a prominent factor affecting treatment adherence in this study. Although epilepsy is sometimes considered as a punishment to the sins in the previous life, religious beliefs positively affects the treatment of epilepsy, complementing the medications. ${ }^{15}$ Figure 3 shows a conceptual model developed by the investigators on the factors and issues affecting treatment adherence as elucidated in this study. In this model, both the PWE and the caregivers aim for good quality of life and seizure freedom, which are both affected by seemingly inter-related factors that should be addressed.

\section{Limitations and recommendations}

In a qualitative study like this, it is important to ensure dependability and credibility. ${ }^{8}$ Dependability is the qualitative version of reliability or reproducibility of a study. In this study, the investigators made sure that the room setup, schedule of the discussion, facilitators, and questions asked during the discussion were almost similar among groups. On the other hand, credibility is the qualitative version of validity, which means that it is able to measure what it intends to measure. In this study, the investigators carefully reviewed the literature in order to come up with a set of guide questions for the discussion. Moreover, the facilitators were psychology graduates who were skilled in conducting a focus group discussion.

This study was subjected to selection bias since it only involved patients and caregivers who volunteered to attend the discussion. Since they volunteered, they were the ones expected to have more concerns with the disease and the data that were extracted from the discussion may actually be overstated. Because of this, the investigators were also limited in making generalization in this study and doing the focus group discussion in another setting and probably to a larger and random sample of participants is recommended. However, the findings of this study may still serve as a guide to the creation of an objective tool, such as a validated questionnaire, to measure treatment adherence among the people with epilepsy, which can eventually promote further improvement in the treatment strategy for epilepsy in the future.

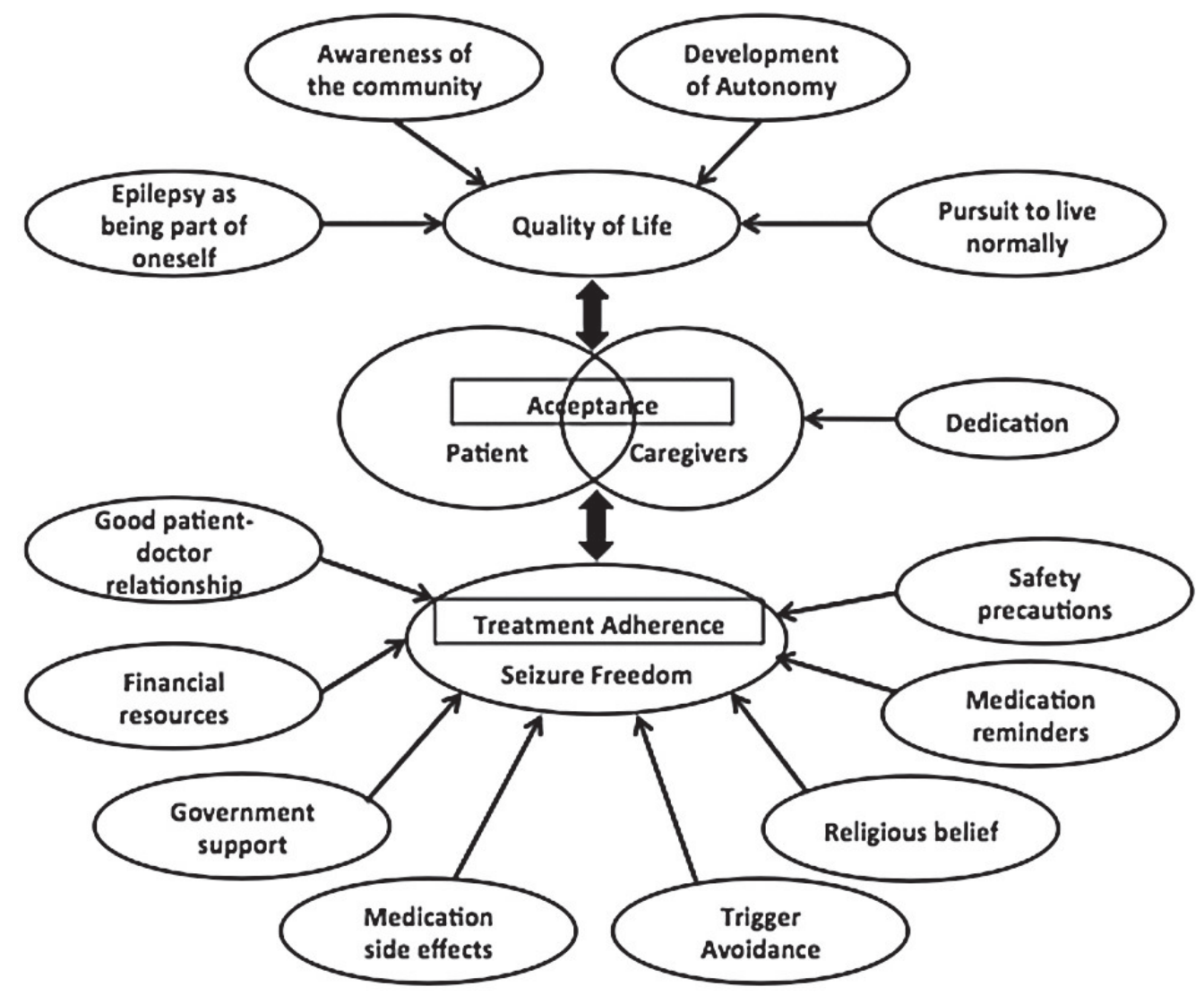

Figure 3. Conceptual model of the factors and issues affecting treatment adherence. 


\section{Conclusion}

This study was able to demonstrate that conducting a focus group discussion was an effective means of eliciting the experiences and issues among PWE and their caregivers. Through a focus group discussion, several factors such as patient-doctor relationship, financial resources, government support, adverse medication effects, religious belief, trigger avoidance, frequent reminders, and safety precautions were elucidated to affect treatment adherence in order to achieve seizure freedom in epilepsy.

\section{Statement of Authorship}

All authors have approved the final version submitted.

\section{Author Disclosure}

All authors declared no conflict of interest.

\section{Funding Source}

This paper was partially funded by the Philippine General Hospital and the authors.

\section{References}

1. Burkhart PV, Sabate E. Adherence to long-term therapies: evidence for action. J Nurs Scholarsh. 2003; 35(3):207.

2. Gabr WM, Shams ME. Adherence to medication among outpatient adolescents with epilepsy. Saudi Pharm J. 2015; 23(1):33-40.

3. Eatock J, Baker GA. Managing patient adherence and quality of life in epilepsy. Neuropsychiatr Dis Treat. 2007; 3(1):117-31.

4. Paschal AM, Ablah E, Wetta-Hall R, Molgaard CA, Liow K. Stigma and safe havens: a medical sociological perspective on African-American female epilepsy patients. Epilepsy Behav. 2005; 7(1):106-15.

5. Morisky DE, Green LW, Levine DM. Concurrent and predictive validity of a self-reported measure of medication adherence. Med Care. 1986; 24(1):67-74.

6. Tan X, Patel I, Chang J. Review of the four item Morisky Medication Adherence Scale (MMAS-4) and eight item Morisky Medication Adherence Scale (MMAS-8). Innov Pharm. 2014; 5(165):1-8.

7. Clisby N, Charnock D. DISCERN/CASP Workshops 2000. Final Project Report. Critical Appraisal Skills Programme, Institute of Health Sciences, Oxford.

8. Sample PL, Ferguson PL, Wagner JL, Elisabeth Pickelsimer E, Selassie AW. Experiences of persons with epilepsy and their families as they look for medical and community care: a focus group study from South Carolina. Epilepsy Behav. 2006; 9(4):649-62.

9. Jacoby A, Snape D, Baker GA. Epilepsy and social identity : the stigma of a chronic neurological disorder. Lancet Neurol. 2005; 4(3):171-8.

10. Jones RM, Butler JA, Thomas VA, Peveler RC, Prevett M. Adherence to treatment in patients with epilepsy: associations with seizure control and illness beliefs. Seizure. 2006; 15(7):504-8.
11. Ridd M, Shaw A, Lewis G, Salisbury C. The patient - doctor relationship: a synthesis of the qualitative literature on patients' perspectives. Br J Gen Pract. 2009;59(561):e116-33.

12. Tan XC, Makmor-Bakry M, Lau CL, Raymond AA, Tajarudin FW. Factors affecting adherence to antiepileptic drugs therapy in Malaysia. Neurol Asia. 2015; 20(3):235-41.

13. Carpay JA, Aldenkamp AP, Van Donselaar CA. Complaints associated with the use of antiepileptic drugs: results from a community-based study. Seizure. 2005; 14(3):198-206.

14. Balamurugan E, Aggarwal M, Lamba A, Dang N, Tripathi M. Perceived trigger factors of seizures in persons with epilepsy. Seizure. 2013; 22(9):743-7.

15. Ismail H, Wright J, Rhodes $\mathrm{P}$, Small N. Religious beliefs about causes and treatment of epilepsy. Br J Gen Pract. 2005; 55(510):26-31.

Supplemental Table 1. Demographic characteristics of focus group discussion participants

\begin{tabular}{|c|c|}
\hline Characteristic & Number (\%) \\
\hline \multicolumn{2}{|l|}{ I. Patients $(n=20)$} \\
\hline Age & 34.9 (Range: $20-54$ years) \\
\hline \multicolumn{2}{|l|}{ Sex } \\
\hline Male & $8(40.0)$ \\
\hline Female & $12(60.0)$ \\
\hline \multicolumn{2}{|l|}{ Marital Status } \\
\hline Married & $4(20.0)$ \\
\hline Single & $15(75.0)$ \\
\hline Separated & $1(5.0)$ \\
\hline \multicolumn{2}{|l|}{ Educational attainment } \\
\hline Elementary & $1(5.0)$ \\
\hline High school & $11(55.0)$ \\
\hline College & $8(40.0)$ \\
\hline \multicolumn{2}{|l|}{ Employment status } \\
\hline Employed & $7(35.0)$ \\
\hline Self-employed & $4(20.0)$ \\
\hline Unemployed & $9(45.0)$ \\
\hline \multicolumn{2}{|l|}{ Onset of seizures } \\
\hline Childhood & $15(75.0)$ \\
\hline 18-44 years old & $4(20.0)$ \\
\hline$>45$ years old & $1(5.0)$ \\
\hline Duration of epilepsy & 16.2 (Range: $1-37$ years) \\
\hline \multicolumn{2}{|l|}{ Most recent seizure } \\
\hline 0-30 days ago & $10(50.0)$ \\
\hline 1-12 months ago & $8(40.0)$ \\
\hline$>1$ year ago & $2(10.0)$ \\
\hline \multicolumn{2}{|l|}{ II. Caregivers $(n=19)$} \\
\hline Age & 48.2 (Range: $21-69$ years) \\
\hline \multicolumn{2}{|l|}{ Relation to patient } \\
\hline Parent & $14(73.7)$ \\
\hline Spouse & $3(15.8)$ \\
\hline Sibling & $2(10.5)$ \\
\hline \multicolumn{2}{|c|}{ Source of funding for treatment } \\
\hline Job salary & $15(78.9)$ \\
\hline Business Income & $3(15.8)$ \\
\hline Donations & $1(5.3)$ \\
\hline
\end{tabular}

